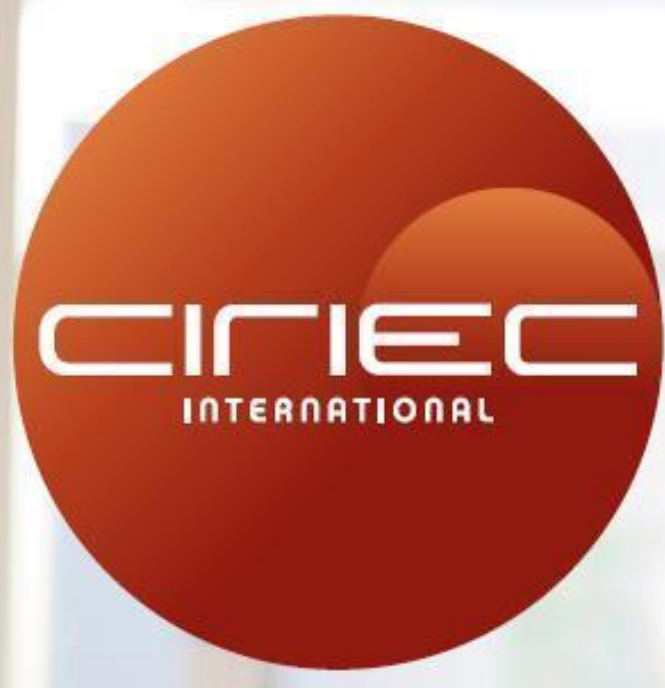

Working Paper

The governance of State-owned Enterprises (SOEs) operating under monopoly situation

Pierre BAUBY

CIRIEC No. 2019/31 
CIRIEC activities, publications and researches are realised with the support of

Les activités, publications et recherches du CIRIEC sont réalisées avec le soutien de
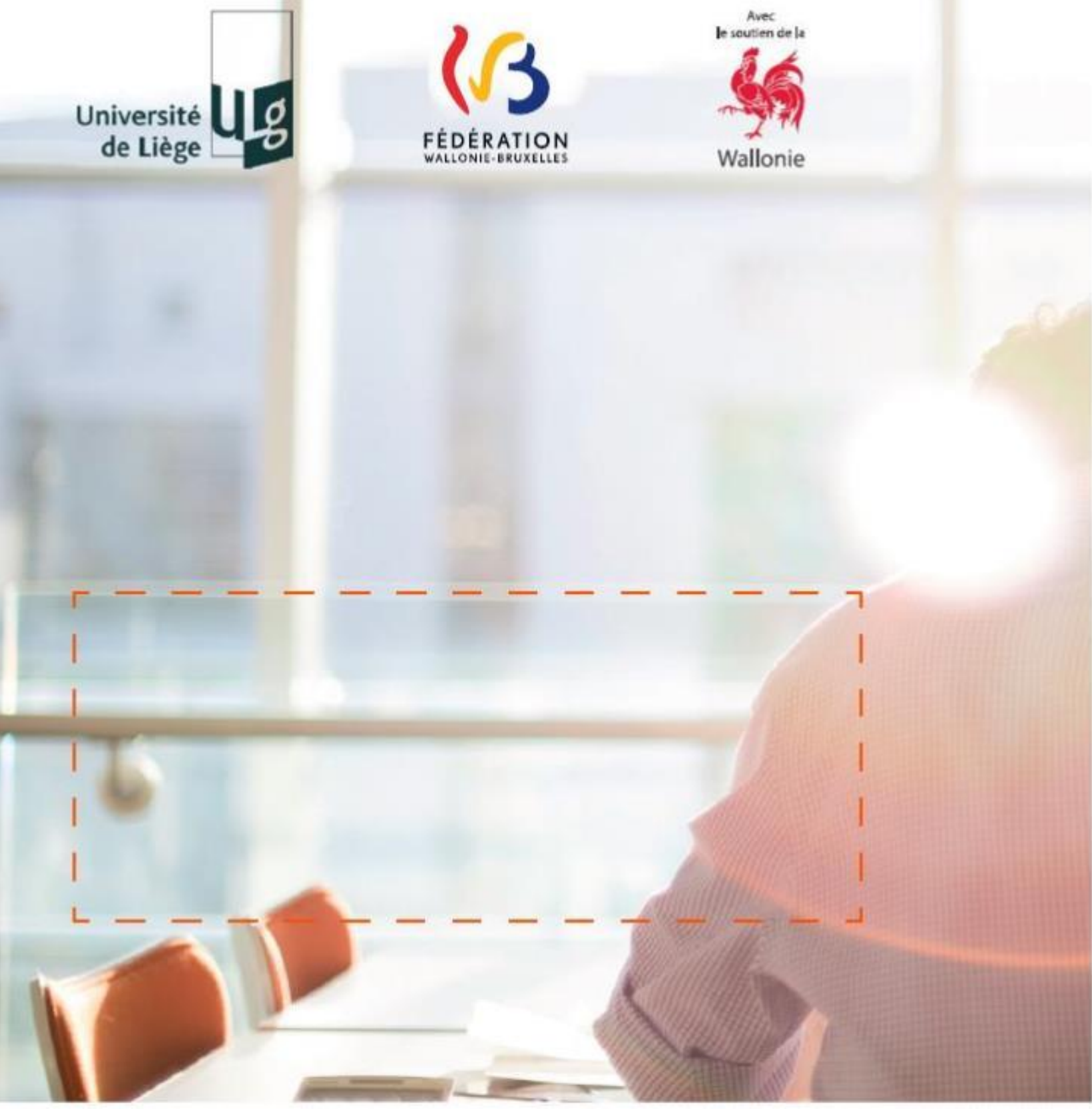


\title{
The governance of State-owned Enterprises (SOEs) operating under monopoly situation
}

\author{
Pierre Bauby ${ }^{1}$
}

Working paper CIRIEC No. 2019/31

\footnotetext{
${ }^{1}$ Ph.D. Institut d'Etudes Politiques (Sciences Po) Paris, Researcher and Professor of Political Science. Chairman of Reconstruire I'action publique (RAP), Director of Observatoire de I'action publique of Fondation Jean-Jaurès. Author in particular of: Service public, services publics, La Documentation Française, Paris, second ed., 2016; European Chapter of UCLG (ed.), Basic Services for All in an Urbanizing World, Routledge, 2014; L'européanisation des services publics, Presses de SciencesPo, Paris, 2011; Mapping of the Public Services in the European Union and the 27 Member States, Brussels, 2010 (Email: bauby.pierre@orange.fr).
} 


\begin{abstract}
This paper aims to treat specific issues about the governance of State-owned Enterprises (SOEs) operating under monopoly situations, in particular the link between regulation, evaluation, control and modernisation of such enterprises.

The survey of the literature reveals a lot of studies on some of these topics, but very few on the link between them and such SOEs'.

The paper addresses in particular the asymmetries of information and expertise between public authorities and SOEs; the strategic role of the State in the EU context, rights and duties of public authorities; how to minimize asymmetries of information between monopoly situations and public authorities; what type of regulatory bodies can be set up; how to implement evaluation both of "regulation" and of the economic and social efficiency of each State-owned Enterprise (SOE); why and how to involve stakeholders' participation.
\end{abstract}

Keywords: Monopoly situations; Asymmetries; Strategic State; Regulation; Evaluation; Participation

JEL Codes: K2; L12; L43; L50 
This paper aims to treat specific issues about the governance of State-owned Enterprises (SOEs) operating under monopoly situations, in particular the link between regulation, evaluation, control and modernisation of such enterprises.

Regulation, evaluation, control, modernisation of SOEs operating under monopoly situation recover a series of issues that we present on the basis of both literature and research and practices, in particular in Europe.

The survey of the literature reveals a lot of studies on some of these topics, but very few on the link between them and such SOEs'. The author advances some proposals in this respect.

\section{A partial literature}

The literature survey reveals a multitude of studies on some of the topics dealt with, but very few on the link between "regulate, finance, evaluate, control, modernise", on one hand, "SOEs' under monopoly situations", on the other.

Since John Stuart Mill (1873) and Léon Walras (1875) "natural monopoly" situations have been subject to important economic literature, from which important controversies have also emerged in relation to the nature, the dimension and the difficulties of the "monopoly" (Allais, 1945).

The same could be said regarding studies on the relations between public enterprises and public authority, in particular with the "agency theory", the phenomenon of asymmetries of information and capabilities, which generates "capture" situations (from Jensen in 1976 to Laffont and Tirole in 2012, through Eisenhardt in 1989 etc.).

Over the last years, we saw renewed studies on SOEs, in particular the works of the World Bank (2008), OECD (2011, 2015), European Commission (2016), Belloc (2014), as well as several CIRIEC researches (Ciriec and Tepsa, 1995; Florio, 2013, Bernier, 2015, a series of working papers and study cases of public enterprises).

The development of "regulatory agencies" has also been largely documented and studied, in particular on the occasion of the opening to competition of services of general economic interest in Europe, since the mid-1980s (for instance, in France, Henry, 1999; Rodrigues, 2000; Commissariat général du Plan, 2003; Bauby, 2011) to implement their possible objectives (CIRIEC 2000):

- To monitor competition and its effectiveness, for example in the case where a public authority takes recourse to a call for tenders to choose 
the operator of a service, or to verify that an operator in a dominant position does not abuse its situation: often it falls to national and European authorities to monitor competition (Competition Council, European Commission); but these latter state their position ex-post, which may trammel the functioning of a sector; besides, the control of competition is but one of the aspects of a regulation system;

- To introduce competition into a sector; regulation is then conceived as being "asymmetric", exercising strict control over the former monopoly and encouraging the "new comers"; such regulation is mostly defined as provisional, pending the existence of a genuinely competitive market; so far, however, the need for specific regulation has not disappeared in those sectors opened to competition since the end of the 1980s (Henry, 1997; Bergougnoux, 2000);

- To ensure that the introduction of competition does not trigger any adverse effects (absence of incentive to invest, negative effects in particular on the long term, a 'disorganisation' of integrated structures, in particular in terms of 'global responsibility' of the operation of a network and in the field of investment, multiplication of negative externalisations, territorial concentrations, etc.) (Henaf, 2001);

- To ensure access of different operators to infrastructure characterised by the existence of a natural monopoly (electrical, gas and rail transport networks, water and waste networks, etc.); this often leads to the setting up of a national regulating authority for each sector, independent in its relationships with the various operators and public authorities, especially where public authorities remain the single or majority shareholder of the incumbent operator or the operator of the network; in such a case, the public authority should state ex ante or continuously its position, so as to allow the good functioning of the sector; this is the basic function assigned to most regulation agencies created in network industries to accompany liberalisation;

- To ensure evolving balance between objectives containing contradictory aspects, in particular between competition and objectives of general interest or public service obligations; it then devolves upon the public authorities, which are responsible of the definitions, arbitrations and controls.

The above shows that the objectives and functions of regulation are various, according to national histories, institutions and traditions and the technical, economic, social and territorial characteristics of each industry. The above does not constitute a "model" that one could simply implement everywhere. 
The works on Public Utilities Commissions (PUC) in the USA should also be reminded. These commissions have been created at the end of the $X I X^{\text {th }}$ century. Their tasks are to control communication, energy and transport public utilities at municipal, state and federal level to avoid the abuse of monopoly situations. The members of these commissions are appointed by public authorities; in some cases, they are elected. Let us recall that in the USA most public utilities are managed by private companies, even if more than $80 \%$ of water services, the majority of public transport and the federal post are public.

More generally, in the 1980s we saw the emergence of the neo-liberal doctrines developed on the basis of the theory of Hayek (1944, 1960, 1976) according to which all public intervention is inefficient and perverse by nature because it would impede the virtuous action of market forces.

Therefore, we only dispose of partial references to answer the question "How to regulate, evaluate, control, modernise SOEs operating under monopoly situation?"

But beyond solutions in terms of privatisations or opening to competition, or the combination of both, few studies have been led in Europe on the regulation, financing, evaluation, control and modernisation of public enterprises in monopoly situations.

\section{Asymmetries of information and expertise between Public authorities and SOEs}

We focus here below on SOEs in monopoly situation, either natural monopoly or a legal or de facto monopoly, territorial and/or temporal monopoly.

A lot of SOEs are also subject to public service tasks, missions and activities that European treaties call "services of general economic interest" (SGEIs).

A natural monopoly is characterised by high capital-intensity, important economies of scale and sub-additive costs, where "a single firm can supply a good or a service to an entire market at a lower cost than could two or more firms" (Mankiw, 1998; Gomez Ibanez, 2007). It's particularly the case of infrastructures of network industries (electricity grids, gas networks, rail transport networks, water and waste management, etc.).

OECD Guidelines show that, "in OECD countries, the rationales for establishing or maintaining state enterprise ownership typically include one or more of the 
following: (1) the delivery of public goods or services where state ownership is deemed more efficient or reliable than contracting out to private operators; (2) the operation of natural monopolies where market regulation is deemed infeasible or inefficient; and (3) support for broader economic and strategic goals in the national interest, such as maintaining certain sectors under national ownership, or shoring up" (OECD, 2015).

In case of "natural monopoly" situations, the State may choose to manage them through SOEs: "Natural monopolies are sectors where it is most effective for production to be undertaken by a single firm. In such cases, the State may deem it more cost efficient to own such enterprises directly rather than to regulate privately-owned monopolies. To clarify the respective policy rationales underpinning their maintenance in state ownership, it can sometimes be useful to classify those SOEs into separate categories and define their rationales accordingly. All elements in the chain of agents involved in the governance of SOEs should be made aware of the government's commitment to the present Guidelines" (OECD, 2015).

Even after opening of the markets to competition, there is still a part of the infrastructure that continues to fall within the scope of a "natural monopoly" in most sectors, one to which the various players (service operators, eligible consumers) have access to.

In all cases, the operator owns better information on the system, which creates asymmetry of information, competence, expertise, etc. compared to other actors (Kuisel, 1984), and conditions for a possible abuse of its monopoly situation (either public or private). So, it is necessary to protect consumers against monopoly or oligopolistic suppliers' power.

More generally, for OCDE, "any public policy objectives that individual SOEs, or groups of SOEs, are required to achieve should be clearly mandated by the relevant authorities and disclosed". The Guidelines provide that "SOEs are sometimes expected to fulfil special responsibilities and obligations for social and public policy purposes. In some countries this includes a regulation of the prices at which SOEs have to sell their products and services. These special responsibilities and obligations should be clearly mandated and motivated by laws and regulations. They could also be incorporated into corporate bylaws. The market and the general public should be clearly informed about the nature and extent of these obligations, as well as about their overall impact on the SOEs' resources and economic performance" (OCDE, 2015).

The typical reference of such a situation in Europe is Electricité de France (EDF), the French public enterprise that had had the quasi-monopoly of generation, 
transport, marketing, export and import of electricity during 50 years in France (Bauby, 2015).

The "EDF model" (Wiéviorka, 1989) is in fact characterised by a quasimonopoly of technical and economical expertise owned by EDF's managers, as well as the fetichisation for technical and economical optimum - "there is only one solution" - that is defined top-down by "experts" and which has surpassed the control capacities of the political and administrative authorities allowing them to have a decisive influence on public decision-making, to that point that ones saw EDF as a "State in the State". Therefore, either because of the French State failures or due to the willingness of actors, EDF's managers had retained the power of the definition of the general interest content, of its limits and of public service constraints.

In parallel and as a counterpoint, in the name of the power of orientation and control of the State, we saw the prompt development of a governmental and administrative picky about control over budgets, investments, tariffs, markets, etc. While globally continuing to meet its missions, EDF, as many other public service enterprises, have been considered by political and administrative public authorities as being instrument of industrial and economic policies and, too often, of conjectural policies unrelated to public services objectives.

Thus, an unbalanced and asymmetrical players' action had been implemented. EDF's managers knew how to use all means they had to reverse "principalagent" relationship with public authorities. More broadly, it would be no exaggeration to say that it was the EDF who made the French energy policy (choice of production models - from "all oil" to "all nuclear" -, investments planning, definition of public service obligations, commercial policy and tariffs setting, etc.).

In the framework of the progressive opening to competition of the electricity sector, along with the creation of a regulatory agency, the French Energy Regulatory Commission (CRE), the legal statute of the EDF had been changed by an Act of 2004. Until then, EDF had been organised as an EPIC (industrial and commercial public establishment / Etablissement public industriel et commercial). The Act of 2004 provided for the transformation of its legal statute and EDF became a shareholder company but the French State had to retain at least $70 \%$ of its shares. Ones could think these institutional changes would contribute to limit the powers of the "historic operator", in particular in its relationships with the State and public authorities. 
In fact, the situation has remained marked by significant asymmetries. For instance, EDF proven its capacity to resist to the willingness of the French President, François Hollande, to close the most ancient nuclear plant (Fessenheim) before the end of its presidential mandate in 2017, as well as to the implementation of the Act on energy transition adopted by the French Parliament in 2015, which provided for the reduction by $50 \%$ of the part of nuclear energy in the energy mix until 2025; or the announcement of the fact that in any circumstances no other nuclear plant will be close before 2029, which postpone the objective of $50 \%$ until at least 2040 in a context marked by a diminution of the electricity consumption in France.

These aspects are often considered arguments to advance some perverse characteristics of the public action and of public enterprises. Even if it is not subject of this article, we should emphasise that the second reference model of organisation of public services - the delegated management to private enterprises - has been subject to similar critics as regards information asymmetry and "capture"... (Bauby, 1998).

\section{Strategic role of the State in the EU context. Rights and Duties of Public Authorities in respect of SOEs?}

A strategic role of the State and more generally of public authorities is needed (Bauby, 1991; Bance, 2016). In fact, they are the only bodies of the public community able to define, decide and implement a global strategy to ensure internal and external security, the organisation of the community, its cohesion, control and development.

Whether it is about classifying an activity as SGEI or deciding its implementation through a SOE, the responsibility of national, regional and local public authorities is essential (Lévêque, 2004). These decision-making responsibilities require the respect of a certain number of obligations. Rights and duties go hand in hand, including those set up by the EU law, even if European SOEs are under the authority of EU Member States.

Therefore:

- The EU neutrality principle, which involves the free choice of ownership of enterprises (nationalisation or privatisation) (Art. 345 TFEU) together with non-discrimination and equal treatment principles imply that the statute of the enterprise does not confer it an advantage compared to its competitors in the internal market, according to the respective organisation of the market in each considered case; 
- At the same time, the transparency principle, the freedom of definition of SGEIs requires a clear definition by public authorities of "their missions" (Art. 14 TFEU) and "particular tasks" (Art. 106 TFEU), providing for obligations to provide the service and public service obligations (PSO) or universal service obligations (USO);

- The free choice of the organisation model of SGEls' missions and tasks (natural monopoly or legal, territorial and/or temporal one; comparative market), respects the proportionality principle, that is to be appropriate to these missions and tasks and to respect the framework of European rules that have been progressively defined and up-dated by European institutions, while either taking into account the specificities of each sector or being set for all SGEls;

- The definition of the management model, either direct provision or inhouse management of services or through externalisation, is the responsibility of national, regional or local public authorities, which observe the European objectives of "high level of quality, safety and affordability, equal treatment and the promotion of universal access and of user rights" (Protocol 26);

- The definition of the financing model for each service, either by the public budget or by users or with the participation of other private or public funds or a combination of all these forms, for instance to implement social, geographical, generational equalisation schemes or equalisation schemes between activities, etc., as well as modes of compensation of the net costs generated by PSO and USO, involves the respect of European state aid rules;

- The setting up of regulatory bodies, as well as the evaluation and control of SOEs and SGEls, and the participation of stakeholders, should be made in accordance with the principles of non-discrimination and independence as regards operators.

The European Union is not a "state" in the conventional sense of the concept, with single unified and imperative norms, but a Union of nation-states based both on some common rules and on important powers of definition, adaptation and initiative, a "wide discretion" (Protocol 26) of Member States.

Whether it is about SGEls, SOEs or SOEs in charge of SGEls, as most SOEs, the main issue for all actors concerned is to successfully combine, in an efficient manner, the European common rules and the rooms of manoeuvre of national, regional and local public authorities in order to define a better balance between possible contradictory aspects. 
Such responsibilities suppose that public authorities own or develop real capacities of steering, control and evaluation of SOEs (Rentsch and Finger, 2015). Their role is essential to define and implement strategies of modernisation and evaluation of SOEs, to fully make use of their role as "organising authorities", which define the public missions and are responsible for their implementation. The concept of "organising authority" has been first employed in the transport sector before being largely used in all fields where the responsibility of public authorities must be clearly defined, carried out and accountable.

An "organising authority" is a public authority which has the final responsibility for the organisation and operation of a socio-economic system, which steers it by deciding the model of organisation and funding, which arbitrates among different or contradictory expectations of stakeholders. A public authority can act in an authoritarian or hierarchical manner, but the concept of organising authority rather refers to the governance associating different stakeholders, which encourages their participation at all levels, which puts into debate the main choices and arbitrations before adopting decisions, which is accountable for its actions.

To this end, an organising authority has at its disposal a range of means, even if it is confronted with a series of difficulties.

\section{What type of regulation is needed? How to minimize asymmetries of information between monopoly situations and Public Authorities? What type of Regulatory bodies can be set up?}

The concept of "regulation" is often used in different ways with different meanings.

The "regulation" of a system refers to its adjustment, according to rules or norms, to a diversity of actions and their effects. Therefore, it embraces the "regulation" in the sense of adoption of norms and conclusion of contracts, their "control", that is the check of their implementation, as well as the needed adaptations. The regulation exists because norms cannot provide for every circumstance, they must be interpreted and they are put into question - in continuous adaptation - according to situations and objectives.

The regulation involves breaking with interventionist, centralist, uniform, bureaucratic and authoritarian conceptions of public action to emphasize the definition and implementation of mid-term and long-term development of 
social systems by taking into account different aspects of the social reality (Thatcher, 2002).

Regulation rests on arbitrations between often contradictory interests and forces. But the preliminary expression of all proposals and issues should be ensured in order to attain a relatively stable and efficient arbitration. Any obstacle of the expression of a part of the social community disables the entire community. Recognizing the existence of opposing interests, of contradictions in the social system is even the condition of its existence and continuity.

The regulation of a monopoly appears even more needed as the operator owns better information on the system, which creates an asymmetry of information compared to other actors, and conditions for a possible abuse of its monopoly situation (either public or private).

Therefore, how could the organising authority perform its duties? Several paths have been proposed. For some, free market and competition would be the best way to find the optimum of any public authority; public enterprises should be privatised and services of general interest should be deregulated. But this would make impossible economic, social, territorial and temporal equalisations and would lead to the dismantling of public service missions, which in turn would contribute to a social dismantling.

Another path would be the reinforcement of the state and bureaucratic controls. But it underestimates the role of users and the partnership role of municipalities. It also perpetuates the financial leadership of the State. Such a path has often facilitated progress, but it has limited effects, as it was not able to balance the structural information imbalances between operators and organising authority, which led to the phenomenon of the "capture of the regulator by the operator".

The creation of "independent" regulatory agencies has been promoted in the framework of the process of Europeanisation of "services of general economic interest", which had been led since thirty years now. This process had passed through the implementation of three types of separation: between the operation and the regulation functions; between shareholder and regulatory functions of public authority; between infrastructures, which most often remain natural monopolies, and services. This dynamic can be found in most EU countries. EU secondary law provides for the creation of sectoral 'independent' regulatory authorities/entities in each Member State, with coordination at EU level. They are in charge of ensuring an effective competition, the efficient operation of the market, non-discriminatory access and equal treatment of operators. 
Thus, in the recent years, there have been set up regulatory agencies of services of general economic interest in all EU countries, in relation with the opening to competition and/or the privatisation of a growing number of activities (communication - telecommunications and postal services; transport - in particular for railway; energy - electricity and gas -; broadcasting; local services such as water, urban heating, etc.). The liberalisation process requires public authorities to ensure that operators observe competition rules, as well as public service obligations.

Besides, competition authorities are in place in all European countries, which also intervene in the various fields of SGEI, in particular to implement the common EU competition rules, in accordance with the 'exclusive' competence conferred by the treaties. There are also specific authorities in charge of consumer protection.

National regulatory agencies may have different functions and legal status, different organisation patterns, competences and powers, according to national traditions and sectoral particularities.

They may be in charge of:

- controlling competition and its effectiveness;

- working for the introduction of competition in a certain field, which leads to 'asymmetric' regulation favouring the competitors of the 'historical model';

- monitoring the introduction of the competition to avoid adverse effects (lack of incentives to investments, multiplication of negative externalities, territorial concentrations, etc.);

- focus on the access to different operators to natural monopoly infrastructure (electricity and gas networks, railway, water and wastewater networks, etc.);

- ensure an evolving balance between contradictory objectives, in particular between competition and public interest or public service obligations.

Regulatory agencies reveal a series of essential challenges as regards services of general interest, in particular:

- the distinction between regulation (adopting norms) and systems of regulation of complex systems;

- the needed definition of the objectives and purposes of the regulation; 
- the necessity to limit or to remedy asymmetries of knowledge, expertise, etc., between operators and regulator;

- the 'independence' issue, in relation with whom and what (the State and public authorities, operators, lobbies, ...? ?), and how, with what guarantees;

- agencies' missions, their composition, operation, means;

- the type of regulation: economic, administrative, quasi-contentious;

- the relationships between regulation and evaluation;

- the levels of regulation (from local to EU level) and their multi-level relationships;

- the democratic participation and multi-actors' regulation...

It is not possible to completely eliminate information and other asymmetries between operators, regulator(s) and public authorities; but it is possible to limit them and to reduce their effects. One has to move from this "two players" game, between regulator and operator(s), from a regulation by "experts" to a regulation of "actors", which integrates, on the one hand, the workers and their trade unions and, on the other hand, individual and industrial, small and big users, at each territorial level, starting with the local level. Due to their diverse experiences, all of them have a lot of information to share, which public authorities are "missing" and they express wishes and demands based on the diversity of their needs. The association of all actors concerned is a mean to reinforce the governance of SGEls and public enterprises.

\section{How to implement evaluation both of "regulation" and of the economic and social efficiency of each SOE?}

The evaluation of SOEs is essential for their evolution in time and space, to better meet the changing needs of consumers, citizens, community and society.

On the one hand, evaluation focus on the relevance of the decisions regarding the organisation and the financing of services, knowing there is no "one model fits all solutions": the specificities of each sector and the historical legacy of each country have to be taken into account, as well as the technical, economic and social evolutions. A better balance between monopoly and competition should be followed, as well as between economic, social and environmental aspects, between the various concerned territories, between different possible financing modes, etc. Only practical experiences and adjustments allow the progressive adaptation of the common rules and their implementation. 
On the other hand, evaluation also focus on the economic and social efficiency of each service operator, on its effectiveness and performance in meeting needs.

Though, the evaluation of public services or services of general interest remains exceptional. A series of arguments have been advanced to justify inertia or obstructions (Bauby, 2016):

- Elected officials are often considered the only capable to define the general interest and therefore public services; developing autonomous procedures of evaluation would be equivalent to suspect them of not being capable to assume their responsibilities;

- Public officials and managers of enterprises providing the service argue they are the only ones capable to handle the complexity, the constraints and the existing possibilities of action; they often emphasize they can only be evaluated by peers;

- The employees of SOEs and of SGEI providers also often consider users or civil society to be less suited to measure services provided to them and to be able to assess their real/effective needs;

- All stresses the complexity of the evaluation of performances, which must take into account not only the price but also the quality, the accessibility and service relationships, all negative and positive externalities.

The evaluation should be:

- multi-criteria, by defining indicators that cover all objectives and missions, by combining them (for instance, the price and the quality, positive and negative externalities, long term and short term, etc.), by taking into consideration multiple and sometimes contradictory objectives, by defining mixed ratios that integrate the various aspects to be measured;

- multi-actors, to take into account the expectations and aspirations of all stakeholders concerned;

- multi-level, at each level of territorial organisation of the community.

Such evaluations also make possible the comparison between different types of service, which can be shared with citizens/users to ensure transparency, to support dialogue and the "shared" modernisation of SOEs (Tõnurist and Karo, 2016). 
The six common objectives provided for in the Protocol 26 annexed to the EU treaties could serve as a basis for real evaluations of SOEs in charge of SGEls (Bauby and Similie, 2014).

\section{Why and how to involve Stakeholders' participation?}

Involving stakeholders supposes reversing the traditional approach according to which objectives and means are defined at the top and then often imposed to the bottom. It is about starting from needs and their evolution by organising their expression through multiples ways. Stakeholders have many information, capacities and expectations allowing both the regulation and modernisation of SOEs and SGEIs.

Rather than relying on a growing number of "experts" or consultants, one could organise the systematic expression of both individual and collective needs and of their development. To this end, multiple means are available today. First, users could directly express their feedback, opinions or proposals whenever they are in touch with SGEI or SOEs. Second, they could make use of the new information and communication technologies, which would allow them not only to present their expectations, needs, opinions and claims, but also to develop interactions between enterprises and users. Third, one could encourage all other forms of oral and written communication, such as citizens' panels, etc.

On this basis, social demands could be aggregated, before being submitted to several expertises, as there is never a single answer to a question or issue but several possible solutions. Therefore, choices and arbitrages are to be made. Thus, users' or consumers' associations could be conferred "drawing rights" to promote expertise that could be different from that of "official" experts.

Summing up the current state of social demands and possible solutions would facilitate the development of a public debate, collective deliberations. These would be different from the "concertation" or "consultations" that are sometimes organised and which often have no impact on the decision-making process. It is not about calling into question the responsibilities of public authorities and their decision-making and arbitration powers. In fact, it is just the opposite, as the choices made by public authorities would be even more relevant, accepted, efficient in their implementation if they would rest on the ex ante participation of all stakeholders. 
Of course, stakeholders' participation takes time but the time spent for information, dialogue and collective deliberation is largely compensated by the more efficient implementation of decisions.

SOEs and SGEls do not exist for themselves, but to answer evolving needs of each inhabitant, community, territory and society.

The implementation of the democratic participation of actors concerned (SOEs' management and employees, trade unions, users and citizens, municipalities and their elected officials) combined with the strive towards a regulation by actors and a multi-criteria and multi-level evaluation allow for a new type of regulation and for developing strategies of modernisation.

Focusing regulation on stakeholders' participation and public deliberation is a variant of "sunshine regulation" (Henry, 1997; De Witte and Saal, 2008). This specific form of regulation has been created in the XIX ${ }^{\text {th }}$ century in the USA and consists of the public exposure of performance in formation to public debate and scrutiny (for example, the Dutch water system).

Thus, if the general public considers practices of monopoly or SOEs as being abusive or illegitimate, operators could be then constraint to voluntary change their practices without formally imposing them to do so.

Putting issues under public scrutiny and transitioning out of "face-to-face" relationships are means that could prevent and limit corruption, fraud, clientelism and politicisation risks.

The objectives of reforms, modernisation and regulation initiatives are to provide better quality services at lowest price for the community and its users. Setting stakeholders as key elements of the systems and of its regulation is a mean to encourage the monopoly and SOEs to improve their efficiency and the quality of the service they render. 


\section{References}

ALLAIS, M. (1945), Economie pure et rendement social, Sirey.

BANCE, P. (dir.) (2016), Quel modèle d'Etat stratège en France ?, PUHR.

BANCE, P. (dir.) (2015), L'internalisation des missions d'intérêt général par les organisations publiques, réalités d'aujourd'hui et perspectives, PURH.

BAUBY, P. (2016), Service public, services publics, 2eme éd., La Documentation française.

BAUBY, P. (2015), "Remettre à l'endroit... le 'rapport principal-agent' », dans Bance, P., 2015, PURH.

BAUBY, P. (2011), L'européanisation des services publics, Presses de Sciences Po.

BAUBY P. (1998), Reconstruire l'action publique, Syros.

BAUBY, P. (1991), L'Etat stratège, Editions ouvrières.

BAUBY, P. and SIMILIE MIHAELA, M. (2014), " Europe " chapter, in UCLG (ed.), Basic Services for All in an Urbanizing World, Routledge.

BELLOC, F. (2014), Innovation in State-Owned Enterprises: Reconsidering the Conventional Wisdom, Journal of Economic Issues, 48(3).

BERGOUGNOUX, J. (2000), Services publics en réseau : perspectives de concurrence et nouvelles régulations, Documentation française.

BERNIER, L. (Ed.) (2015), Public Enterprises Today: Missions, Performance and Governance, Learning from Fifteen Cases, Peter Lang.

CIRIEC (2000), Services of General Economic Interest in Europe, Regulation, Financing, Evaluation, Good practices, ed. by CIRIEC and CEEP, Liège.

CIRIEC and TEPSA (1995), Les entreprises publiques dans I'Union européenne : entre concurrence et intérêt général, Pédone.

CIRIEC Working Papers on case studies of public enterprises (2013-2015), http://www.ciriec.uliege.be/publications/wp/

Commissariat général du Plan (2003), Réguler les services publics en réseaux: l'expérience européenne, La Documentation française.

DE WITTE, K., and David S. SAAL (2008), 'Is a Little Sunshine All We Need? On the Impact of Sunshine Regulation on Profits, Productivity and Prices in the Dutch Drinking Water Sector'. Open Access publications from Katholieke Universiteit Leuven urn: hdl:123456789/200140. Katholieke Universiteit Leuven. http://ideas.repec.org/p/ner/leuven/urnhdl123456789-200140.html

EISENHARDT, K. M. (1989), Agency theory: An assessment and review, Academy of Management Review.

European Commission (2016), State-Owned Enterprises in the EU: Lessons Learnt and Ways Forward in a Post-Crisis Context, Institutional Paper 31. 
FLORIO, M. (2013), Network Industries and Social Welfare. The experiment that reshuffled European Utilities, Oxford University Press.

GOMEZ-IBANEZ, J.A. (2007), Alternatives to Infrastructure Privatization Revisited: Public Enterprise Reform from the 1960s to the 1980s, World Bank Policy Research Working Paper.

HAYEK, F. von (1944), The road to Serfdom, Routledge Press.

HAYEK, F. von (1960), The Constitution of Liberty, London and Henley-Routledge and Kegan Paul.

HAYEK, F. von (1976), Law, Legislation and Liberty, Vol II, The Mirage of Social Justice, Routledge and Kegan Paul.

HENAF, G. (dir) (2001), Concurrence et services publics: enjeux et perspectives, Rennes, PUR.

HENRY, C. (1997), Concurrence et services publics dans I'Union européenne, PUF.

KUISEL RICHARD, F. (1984), Le capitalisme et l'Etat en France. Modernisation et dirigisme au XXe siècle, Gallimard.

LAFFONT, J-J. et TIROLE, J. (1993), Theory of Incentives in Procurement and Regulation, Cambridge, MIT Press

LÉVÊQUE, F. (2004), Economie de la réglementation, La Découverte.

MANKIW, G. N. (1998), Principles of Economics, Dryden Press.

MILL, J. S., 1873, Principes d'économie politique, Lib. Guillaumin.

OECD (2011), State-Owned Enterprise Governance Reform: An Inventory of Recent Change, Paris, OECD.

OECD (2015), Guidelines on Corporate Governance of State-Owned Enterprises, 2015 Edition, OECD.

RENTSCH, C. and FINGER, M. (2015), Yes, No, Maybe: The Ambiguous Relationships between State-Owned Enterprises and the State, Annals of Public and Cooperative Economics, Vol. 86, Issue 4.

RODRIGUES, S. (2000), La nouvelle régulation des services publics en Europe, TEC§DOC.

THATCHER, M. (2002), Delegation to Independent Regulatory Agencies in Western Europe. West European Politics

https://ecpr.eu/Filestore/PaperProposal/995b4a43-0efc-4fbc-b7ebb2d026f4c04e.pdf

TÕNURIST, P. and KARO, E. (2016), State Owned Enterprises as Instruments of Innovation Policy, Annals of Public and Cooperative Economics, Vol. 87, Issue 4.

VAGLIASINDI, M. (2008), Governance Arrangements for State Owned Enterprises, Policy Research Working Paper, Washington DC, World Bank. 
WALRAS, L. (1875), "L'État et les chemins de fer », Revue du Droit Public et de la Science Politique, 1897.

WIEVIORKA, M., TRINH, S. (1989), Le modèle EDF, La Découverte. 
This yearly series of working papers (WP) aims to publish works resulting from the scientific network of CIRIEC. The WPs are subject to a review process and are published under the responsibility of the President of the International Scientific Council, the president of the scientific Commissions or the working groups coordinators and of the editor of CIRIEC's international scientific journal, the Annals of Public and Cooperative Economics.

These contributions may be published afterwards in a scientific journal or book.

The contents of the working papers do not involve CIRIEC's responsibility but solely the author(s') one.

The submissions are to be sent to CIRIEC (iriec@uliege.be).

Cette collection annuelle de Working Papers (WP) est destinée à accueillir des travaux issus du réseau scientifique du CIRIEC. Les WP font l'objet d'une procédure d'évaluation et sont publiés sous la responsabilité du président du Conseil scientifique international, des présidents des Commissions scientifiques ou des coordinateurs des groupes de travail et du rédacteur de la revue scientifique internationale du CIRIEC, les Annales de l'économie publique, sociale et coopérative.

Ces contributions peuvent faire l'objet d'une publication scientifique ultérieure.

Le contenu des WP n'engage en rien la responsabilité du CIRIEC mais uniquement celle du ou des auteurs.

Les soumissions sont à envoyer au CIRIEC (ciriec@uliege.be).

This working paper is indexed and available in RePEc

Ce working paper est indexé et disponible dans RePEc

ISSN 2070-8289

ISBN 978-2-931051-30-6

EAN 9782931051306

http://doi.org/10.25518/ciriec.wp201931

D/2019/1406/31-d 


\section{WP Collection 2019}

2019/01 Évolutions récentes de l'économie sociale dans l'Union européenne Rafael CHAVES \& José Luis MONZÓN

2019/02 Recent Evolutions of the Social Economy in the European Union Rafael CHAVES \& José Luis MONZÓN

2019/03 Evolución reciente de la economía social en la Unión Europea Rafael CHAVES \& José Luis MONZÓN

2019/04 Die jüngsten Entwicklungen der Sozialwirtschaft in der Europäischen Union Rafael CHAVES \& José Luis MONZÓN

2019/05 Recente ontwikkelingen in de sociale economie in de Europese Unie Rafael CHAVES \& José Luis MONZÓN

2019/06 Italian cooperatives: an analysis of their economic performances, employment characteristics and innovation processes based on combined used of official data Carlo BORZAGA, Manlio CALZARONI, Chiara CARINI, Massimo LORI

2019/07 Rôle de l'Innovation Sociale dans le Développement Socioéconomique au Maroc : Premières Constatations à partir de la Littérature, et Etude de Cas de 4 Associations Socialement Innovantes Abdellatif BOUAZZA \& Youssef NAFIL

2019/08 De l'intérêt de créer un nouveau concept : la lucrativité limitée Laetitia DRIGUEZ

2019/09 International City Network and Public-Private Cooperation for Urban WaterEnvironment Management: A Study of Japanese Public Water Services' Overseas Expansion Naoki FUJIWARA

2019/10 Partnering with Civil Society Organizations. The role of volunteers and not for profit organizations in the provision of welfare services Federica VIGANÒ \& Andrea SALUSTRI

2019/11 ICT and Ethical Finance: Fostering Social Innovation and Financial Inclusion Gian-Luca GASPARINI \& Aurora PROSPERO

2019/12 New Trends in the Social and Solidarity Economy Regarding Agriculture and Food: A Comparison between France and India Antoine PERRIN

2019/13 Workers BuyOut: why employee-owned enterprises are more resilient than corporate business in time of economic and financial crisis? The case of Emilia-Romagna Region Andrea BASSI \& Alessandro FABBRI

2019/14 How Social Enterprises Contribute to Alternative Food Systems Anastasia COSTANTINI, Gianluca PASTORELLI \& Alessia SEBILLO 
2019/15 Measuring the Impact of a Social Enterprise - Case Study CONCORDIA Bakery, Romania Irina-Sinziana OPINCARU \& Doina CRÂNGAȘU

2019/16 Vers un nouveau paradigme ancré dans les pratiques d'économie solidaire : le délibéralisme Éric DACHEUX \& Daniel GOUJON

2019/17 Social enterprises role in Romanian welfare system Mihaela LAMBRU \& Claudia PETRESCU

2019/18 Community financing in the German organic food sector: a key for sustainable food systems?

Gerlinde BEHRENDT, Sarah PETER, Simone STERLY \& Anna Maria HÄRING

2019/19 Self-Management Report in Brazil - Technical Concepts and Challenges Daniel Francisco NAGAO MENEZES

2019/20 Creación de un nuevo bien común para las cooperativas agrícolas: Big data, TIC e intercambio de datos Cynthia GIAGNOCAVO \& Daniel HERNÁNDEZ CÁCERES

2019/21 Job Quality in Economy for the Common Good Firms in Austria and Germany Laia OLLÉ-ESPLUGA, Johanna MUCKENHUBER \& Markus HADLER

2019/22 Social Innovation - Scaling Social Impact: a Danish Case Study Roger SPEAR \& Carman Ka Man CHAN

2019/23 Shared-Services Cooperatives: Strengthening Local Economies through Collaboration Christina CLAMP, Eklou AMENDAH \& Carol COREN

2019/24 Les bonnes pratiques en matière de politiques publiques relatives à l'économie sociale européenne, à la suite de la crise économique Rafael CHAVES \& José Luis MONZÓN

2019/25 Best practices in public policies regarding the European Social Economy post the economic crisis

Rafael CHAVES \& José Luis MONZÓN

2019/26 Buenas prácticas en las políticas públicas relativas a la economía social europea tras la crisis económica

Rafael CHAVES \& José Luis MONZÓN

2019/27 Platform Cooperativism in Italy and in Europe

Francesca MARTINELLI, Samuele BOZZONI, Simone CAROLI, Francesca

TAMASCELLI \& Giuseppe GUERINI

2019/28 Promoting social economy in emergent EU countries: Potential of the social economy in Slovakia

Lenka PČOLINSKÁ

2019/29 La Red Eusumo: instrumento público al servicio los ODS en Galicia María BASTIDA \& Ana OLVEIRA 
2019/30 Falsas cooperativas de trabajadores y medidas adoptadas por los poderes públicos en España para combatirlas

Gemma FAJARDO

2019/31 The governance of State-owned Enterprises (SOEs) operating under monopoly situation

Pierre BAUBY 


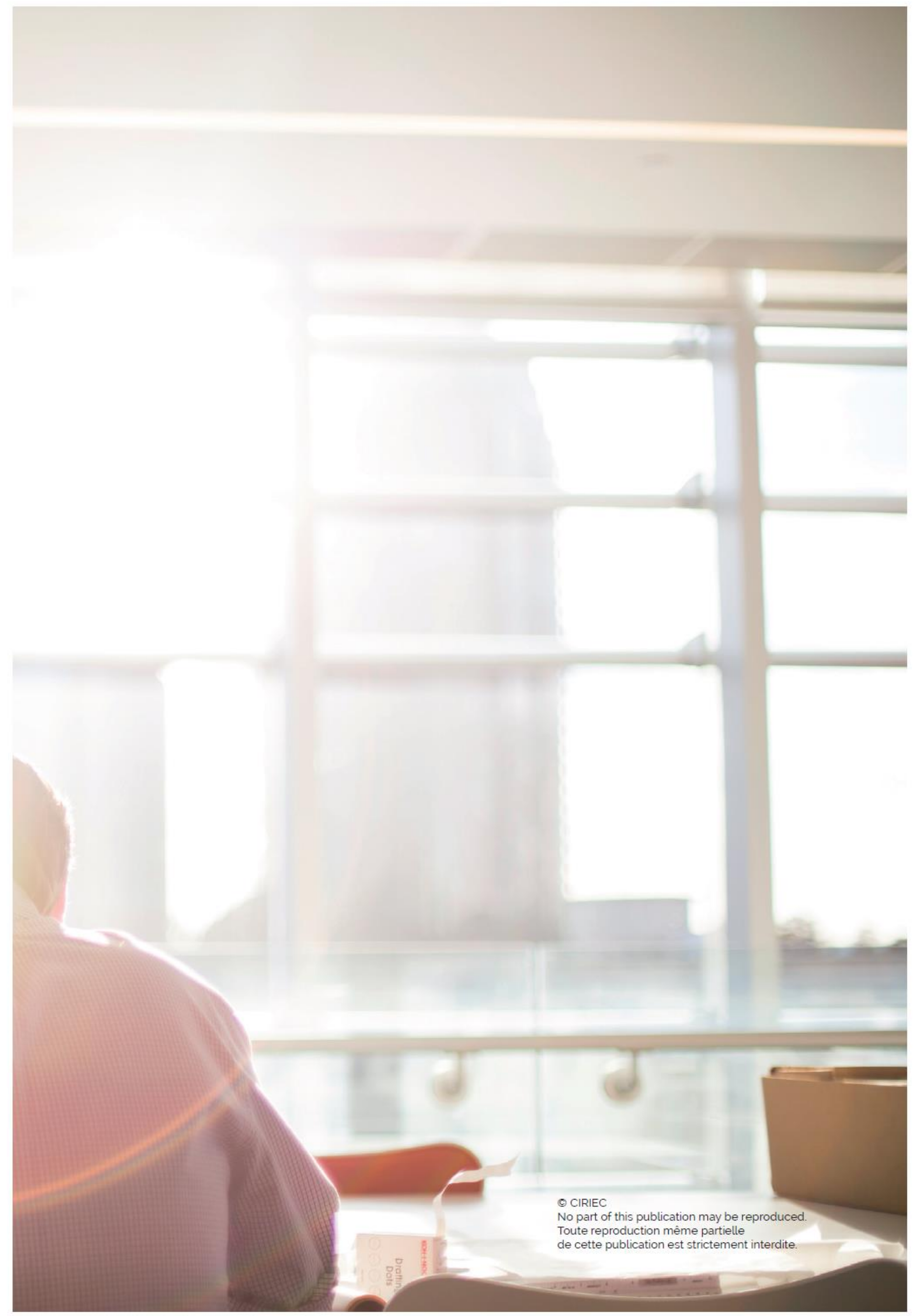


CIRIEC (International Centre of Research and Information on the Public, Social and Cooperative Economy) is a non-governmental international scientific organization.

Its objectives are to undertake and promote the collection of information, scientific research, and the publication of works on economic sectors and activities oriented towards the service of the general and collective interest: action by the State and the local and regional public authorities in economic fields (economic policy, regulation); public utilities; public and mixed enterprises at the national, regional and municipal levels; the so-called "social economy" (not-for-profit economy, cooperatives, mutuals, and non-profit organizations; etc.).

In these fields CIRIEC seeks to offer information and opportunities for mutual enrichment to practitioners and academics and for promoting international action. It develops activities of interest for both managers and researchers.

Le CIRIEC (Centre International de Recherches et d'Information sur l'Economie Publique, Sociale et Coopérative) est une organisation scientifique internationale non gouvernementale.

Ses objectifs sont d'assurer et de promouvoir la collecte d'informations, la recherche scientifique et la publication de travaux concernant les secteurs économiques et les activités orientés vers le service de l'intérêt général et collectif : l'action de l'Etat et des pouvoirs publics régionaux et locaux dans les domaines économiques (politique économique. régulation) : les services publics : les entreprises publiques et mixtes aux niveaux national, régional et local: « l'économie sociale » : coopératives, mutuelles et associations sans but lucratif : etc.

Le CIRIEC a pour but de mettre à la disposition des praticiens et des scientifiques des informations concernant ces différents domaines, de leur fournir des occasions d'enrichissement mutuel et de promouvoir une action et une réflexion internationales. Il développe des activités qui intéressent tant les gestionnaires que les chercheurs scientifiques.

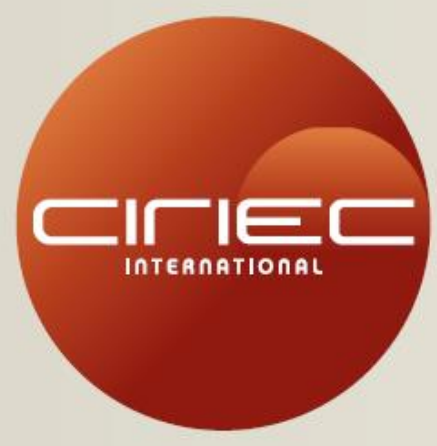

INTERNATIONAL CENTRE OF RESEARCH AND INFORMATION ON THE PUBLIC, SOCIAL AND COOPERATIVE ECONOMY-AISBL

CENTRE INTERNATIONAL DE RECHERCHES ET D'INFORMATION SUR L'ÉCONOMIE PUBLIQUE, SOCIALE ET COOPÉRATIVE - AISBL

Universite de Liège | Quartier Agora | Place des Orateurs 1 | Bātiment B33 boite 6 | BE-4000 Liege (Belgium) | T+32(0)436627 46 | F+32(0)43662958 ciriec@ulg.ac.be | www.cirieculg.ac.be 